https://doi.org/10.52240/1857-2367.2020.2(21).39

\title{
CONTRIBUȚII LA STUDIUL PARTICULARITĂȚILOR BIOLOGICE ALE UNOR SPECII DIN GENUL SCUTELLARIA L. ÎN CONDIṬII DE CULTURĂ
}

\author{
Nina CIOCÂRLAN \\ Grădina Botanică Națională (Institut) "Al. Ciubotaru”, \\ Chișinău, Republica Moldova
}

\begin{abstract}
The paper presents the results of the study on three medicinal species of the genus Scutellaria L. (S. baicalensis Georgi, S. altissima L., S. albida L.), known for their therapeutic and ornamental properties. The phenological phases, the morphometric parameters and the growing rhythm of the plants were recorded. The biological peculiarities of the plants in ex-situ conditions were evaluated. The plants have shown a high adaptive potential, demonstrating the perspective of their cultivation over large areas.
\end{abstract}

Key words: Lamiaceae, Scutellaria, therapeutic effects, medicinal uses, biological features.

Genul Scutellaria L. (familia Lamiaceae) include circa 350 de specii, răspândite în Europa, SUA și Asia de Est. În flora spontană a Republicii Moldova se întâlnesc 4 specii. Studiul de față se referă la trei specii din genul Scutellaria L. (Scutellaria baicalensis, S. altissima și $S$. albida), importante din punct de vedere terapeutic, dar și cu deosebită valoare ornamentală.

Specia S. baicalensis are o lungă istorie de utilizare în medicina tradițională, precum și în cea modernă. Multiple cercetări științifice au demonstrat faptul că flavonoidele sunt constituenții chimici de bază ce induc efectul antiviral, antiinflamator, hepatoprotector, antioxidant, antimicrobian, antialergic și sedativ al plantei [2]. Studii fitochimice recente relevă faptul că extractele din rădăcinile și tulpinile speciei $S$. altissima posedă proprietăți antioxidante și, prin urmare, pot fi benefice în prevenirea bolilor legate de stresul oxidativ, cum este cancerul, bolile cardiovasculare și cele inflamatorii [1]. Partea aeriană a speciei $S$. albida conține iridoide, scutelloside, derivați fenolici, ulei volatil cu componenții de bază linaloolul $(52,63 \%)$ și trans-nerolidolul $(9,03 \%)$. Datorită conținutului înalt de linalool planta posedă un înalt efect toxic împotriva unui spectru larg de bacterii. Pe lângă acțiunea antibacteriană, planta posedă efect antioxidant și antimicrobian [3].

Experiențele au fost efectuate în câmpul experimental al colecției de plante medicinale din Grădina Botanică Naţională. Plantele de S. baicalensis au fost obţinute prin schimbul internaţional de seminţe cu Grădina Botanică din Lodz, Polonia, în anul 2006. Specia S. altissima, fiind spontană, a fost colectată din populații naturale (satul Hulboaca, municipiul Chișinău) și transplantată pe loturile experimentale din colecţia de plante medicinale. Specia S. albida conform datelor bibliografice este înregistrată în colecție din anul 1985. Studiul particularităţilor de creștere și realizare a fazelor fenologice la plantele cultivate a fost efectuat conform îndrumărilor metodologice utilizate pe larg în prezent [4].

Studiul particularităților biomorfologice ale speciilor alohtone din genul Scutellaria L. (S. baicalensis și S. albida) au demonstrat un potențial adaptiv înalt al plantelor în condițiile pedoclimatice din Republica Moldova, demonstrând perspectiva cultivării lor pe arii extinse. În condițiile țării nostre plantele de S. albida înregistrează un ritm normal 
de creștere și dezvoltare cu realizarea întregului program ontogenetic. Plantele în condiții de cultură au atins înălțimea de $30-40 \mathrm{~cm}$. Pentru $S$. baicalensis este caracteristică o productivitate înaltă de semințe. Semințele păstrează capacitatea de germinare timp de 3 ani cu un coeficient de germinare de $70-80 \%$. Cercetările privind particularitățile biologice ale plantelor în condiții de cultură au demonstrat faptul, că exemplarele mature nu formează un sistem de rădăcini adventive satisfăcător care ar asigura propagarea plantelor pe cale vegetativă. Astfel, plantele au fost înmulțite prin semințe. Specia spontană S. altissima a demonstrat un ritm normal de creștere și dezvoltare în condiții ex-situ, aceasta manifestându-se prin realizarea întregului program ontogenetic și dimensiuni ai parametrilor morfologici mai mari decât în populaţii naturale. În condiții de cultură dezvoltarea vegetativă a plantelor durează circa 45 de zile. Perioada de înflorire durează aproximativ 30 de zile. La această etapă de dezvoltare s-a notat o înălțime a plantelor de $45-60 \mathrm{~cm}$.

Identificarea, cercetarea şi introducerea în cultură a unor specii de Scutellaria L., mai puțin utilizate în republica noastră, va contribui la îmbogățirea sortimentului de plante medicinale de interes, care ar putea constitui surse noi de materie primă pentru industria farmaceutică.

Cercetările au fost realizate cu suportul ANCD în cadrul proiectului „Cercetarea şi conservarea florei vasculare și macromicobiotei din Republica Moldova”, cifrul 20.80009.7007.22 (contract de finanțare Nr. 71/PS/2020).

\section{BIBLIOGRAFIE}

1. Grzegorczyk-Karolak I. Study on the chemical composition and antioxidant activity of extracts from shoot culture and regenerated plants of Scutellaria altissima L. //Acta Physiol. Plant., 2015, vol. 37, p. 1736.

2. Kowalczyk E. et al. Pharmacological effects of flavonoids from Scutellaria baicalensis. // Przegl Lek., 2006, vol. 63(2), p. 95-96.

3. Skaltsa H.D. et al. Composition and antimicrobial activity of the essential oil of Scutellaria albida ssp. albida from Greece. // Planta Med, 2000, vol. 66(7), p. 672-674.

4. Майсурадзе Н. И., Черкасов О. А., Тихонова В. Л. Методика исследований при интродукции лекарственных растений //ЦБНТИ. Сер. Лекарств. растениеводство. М., 1984, №3, 33 стр. 